\title{
Fostering in European common shrews Sorex araneus (Soricidae, Insectivora)
}

\author{
Werner HABERL*
}

\begin{abstract}
Haberl W. 1996. Fostering in European common shrews Sorex araneus (Soricidae, Insectivora). Acta Theriologica 41: 433-438.

The successful rearing of young Sorex araneus Linnaeus, 1758 by conspecific foster mothers is reported. Nursing shrews showed no aversion towards the presence of strange young in the nest, irrespective of age and size differences, as well as non-familiar odours of these young. Two adults put in the same container with their young showed no signs of aggression, even after successive removal of the young. The observed phenomena suggest that either olfactory cues are not effective at this stage of development or that maternal instinct inhibits the contradictory information of these cues.

Institute of Zoology, University of Vienna, Althanstrasse 14, A-1090 Vienna, Austria

Key words: Sorex araneus, shrews, fostering, adoption, maternal behaviour, olfactory communication, intraspecific aggression
\end{abstract}

\section{Introduction}

Most shrew species, especially members of the subfamily Soricinae are well known for their solitary lifestyle and their ferocious habits towards conspecifics. Aggressive behaviour in solitary shrews develops gradually during the late nestling period and ensures the timely leaving of the nest to make way for a possible following litter, dispersal and distribution of territories. Towards the end of the weaning period, young shrews explore the surroundings of the nest and increasingly become independent, until one day they are rejected and driven away by their mother. This mechanism has been explained by the mother's inability to recognize her young after longer periods of separation (Crowcroft 1957).

In this context observations on maternal behaviour, especially regarding the adoption of strange young, should be worthy further attention. Reviewing the literature on shrew research (Haberl 1995) reveals that relevant observations are scarce and mainly restricted to the more sociable species of the subfamily Crocidurinae (Crocidura russula and Suncus murinus). The adoption of young

\footnotetext{
*Present address: Hamburgerstrasse 11/17, A-1050 Vienna, Austria.

E-mail: shrewbib@sorex.vienna.at, URL: http://members.vienna.at/shrew
} 
Soricinae (Neomys fodiens) has been described only once (Michalak 1983). The phenomenon of fostering in small rodents (Microtus pennsylvanicus) has received attention from a behavioural point of view by McGuire and Novak (1987) and McGuire (1988).

In the course of my studies on Austrian shrews (Haberl 1993), I have had the opportunity to observe maternal behaviour and fostering following multiple experimental exchanges of litters in Sorex araneus Linnaeus, 1758.

\section{Material and methods}

Three female gravid shrews Sorex araneus, trapped live in 1989 , were caged separately in glass terraria $(80 \times 35 \times 30 \mathrm{~cm})$ containing a ground layer of $5-10 \mathrm{~cm}$ of peat and sufficient cover, provided by pieces of wood, stones, foliage and grass-tuft with rootstocks. The shrews were supplied ad libitum with various invertebrates (meal-worms, snails, earthworms) and rodent carcasses. Cotton wool was provided as additional nesting material.

The litters observed consisted of 2 young born on June 28 (female A and young a1 and a2), 6 young born on June 29-30 (female B and young b1, b2, b3, b4, b5 and b6) and 3 young born on July 5 (female $\mathrm{C}$ and young $\mathrm{c} 1, \mathrm{c} 2$ and $\mathrm{c} 3$ ). The original litter size of shrew A was 6 , but 2 young were either born dead or died shortly after parturition and 2 more died within the first 5 days.

From birth, the young were temporarily removed from their nest to obtain daily weight and size measurements and photo-documentation. No gloves were used when handling shrews. The young were individually marked using a waterproof felt pen.

Exchange of young was conducted during the absence of the adult. To facilitate direct observation, after careful opening, the nests were covered with a plate of glass and made dark with black cardboard, weighed down by a piece of bark during non-observational periods.

\section{Results}

From birth, it was possible to temporarily remove young shrews from the nest for purposes of daily size and weight measurements, without difficulty. The nursing mothers showed no aversion to these disturbances and the human odour, their young must have received during handling.

Out of curiosity I took the risk of moving a young shrew (b1, age 5 days) from its own nest to that of another lactating female (weaning the 2 young a1 and a2, which were slightly older). The foster mother merely reacted by moving the nest and transporting its own as well as the foreign young to the new site (July 4 th, 1989).

The unforeseen and sudden death of a nursing shrew (B) on July 14th, 1989 forced me to shift its 5 remaining young b2, b3, b4, b5 and b6 (14-15 days old), who, according to the state of decay of the adult, must have been lying with their dead mother for several hours. The young were apparently undernourished and on the verge of dying. They were put out to nurse with the lactating shrew A, while its 3 "own" young (a1, a2, b1) were temporarily taken into human care and hand-fed with fat-enriched cow's milk. 
The foster mother immediately weaned her new "litter" and showed no irritation at neither the sudden change in number (5 instead of 3) nor the difference in age or size and the strange odour of the young. After only 15 minutes, one of the young which had followed the foster mother out of the nest, found its way back on its own.

On the same day I conducted the following exchanges: 2 of the hand-reared shrews ( $\mathrm{a} 1$ and $\mathrm{b} 1$ ) were put in with female A, while the young b6 was taken into human care together with a2. Female A, now having 6 young (a1, b1, b2, b3, b4 and b5) to nurse, merely reacted by enlarging the nest. In the evening, b6 was given to another female (C), who was weaning her own 3 young (age 9 days). The stranger was adopted irrespective of the 1 week difference in age and its intense movements in the nest. The same individual was exchanged once more 4 days later (b6 for b2).

The shrew a2 (age 16 days) was kept alive by hand-rearing for almost 3 days.

The young of all 3 litters (age $4-5$ weeks) could be put together in a small container without causing aggression. The shrews sought contact, huddled, tried to crawl underneath one another and sized each other up intensely. Adding one of the foster mothers did not change reactions. The adult female was followed and prodded in the nasal, abdominal and anal region with the snout. Furthermore, the addition of the second female involved no complications. There was no apparent sign of antagonistic behaviour. To my astonishment, the 2 adult females remained peaceful even after successive removal of all young shrews. This situation could be produced repeatedly.

All young shrews except the young originating from litter B, developed normally. The shrews of litter B were slightly retarded in growth, which is attributed to malnourishment during the critical period prior to the death of their mother and the foster mother's inability to quickly produce sufficient quantities of milk.

\section{Discussion}

This is the first record of young Sorex araneus being accepted at an early age and successfully raised by conspecific foster mothers. Dehnel (1952) observed that young common shrews would not be recognized or adopted by their mother after a period of separation of 5-6 hours, which was seen as an indication of the shrews' solitary lifestyle. Michalak's $(1982,1983)$ observations on Neomys anomalus and $N$. fodiens were contrary: female adult water shrews showed no aggression towards their young (age 4 weeks) even after having been separated for about 8-60 hours. Young $N$. fodiens were also adopted by lactating foster mothers (Michalak 1983). This phenomenon was explained by a marked maternal instinct as well as an inability to discriminate between their own and foreign young (Michalak 1987). Vogel (1969) could put 4 young Crocidura russula (age 7 days) into a nest of a conspecific female raising her own 12-day old offspring. Also young mice and voles (Mus musculus, Microtus agrestis) have been reported to be fostered by shrews 
(Wahlström 1929, Rozmus 1961, Blus and Johnson 1969, Grünwald and Möhres 1974, Dryden 1980). The rodents were treated by the shrews Crocidura russula like their own young and even urged to caravan formation (Grünwald and Möhres 1974). Baxter (1993) reports the successful raising of Crocidura flavescens by another female but points out that this African species is not social at all (R. Baxter, pers. comm.).

In view of my own observations on fostering and the non-aggressive behaviour of females towards each other in the presence of the young of different litters, I believe that either olfactory cues are not effective at this stage of development or that maternal instinct inhibits the contradictory information of these cues. It seems unlikely that the foster young do not produce an odour which the foster mother finds foreign or strange, but R. Baxter (pers. comm.) seemed to have arrived at a similar conclusion. However, it must also be taken into account that the prior handling of the shrews might have disguised their specific odour.

The persistent peaceable behaviour of the 2 adults after removal of the young may be explained by a confusion of prevailing instincts and non-corresponding olfactory information in this completely unnatural experimental situation. But it is also possible that the presence of young leads to a reduction or inhibition of aggressive behaviour in nursing adults.

The phenomenon of fostering has only been proved experimentally in captivity. We do not know if this behaviour also occurs in solitary shrews in the wild. This would involve maternal reactions to the plaintive cries of deserted strange young (Haberl 1993), whose mother might have died or been killed by a predator. The question is whether these young would be regarded as "prey" or if their behaviour induces maternal behaviour in the strange female, ie the young have an alarm call with a "general effect", causing the female to transport them to her own nest and to adopt them. In this connection the observation of a strange young (Crocidura russula) at the age of 3 days being carried into the nest by a gravid fenale (Vogel 1969) should receive further attention. In order to answer the questions posed, additional research is necessary and would have to include field experiments or investigations in very large enclosures.

It is little wonder that relevant observations are very rare, since the exrerimental exchange of litters involves a high risk and could be fatal to the young helpless shrews. If it would not have been for the unfortunate death of one of my nursing females, which forced me to conduct the exchanges of young that I have described, I probably would not have taken the risk of losing my experimental animals.

I have had no opportunity to test the possibility of cross-fostering using different shrew species. Different milk composition, odour cues or behavioural dispositons might be a problem in successful weaning. Baxter (1993) failed to coerce Crocicura hirta and Myosorex varius to act as foster parents for young Crocidura flavescens. Churchfield (1990) reports Sorex araneus fostering 3-day old Crocidura suaveden.s until the foster mother died. 
My attempt to hand-rear young Sorex araneus was unsuccessful, mainly due to wrong milk composition, absence of adequate nest and heating facilities and, most of all, lack of manpower. Nevertheless, I could keep a shrew (age 16 days) alive for almost 3 days. For reports on attempts of hand-rearing refer to Wahlström (1928), Slipp (1942), Niethammer (1950), Buttler (1953), and Baxter (1993).

I believe that my new observations of fostering in soricine shrews contribute to the further understanding and discussion of maternal instinct, olfactory perception and communication, as well as, mechanisms of intraspecific tolerance in shrews in general. The advantages of alloparental care and adoption in comunally nesting mammals (eg many rodents) have been described by Riedman (1982). Further studies will be neccessary in order to discuss the evolutionary significance, if any, of this phenomenon in solitary shrews.

\section{References}

Baxter R. M. 1993. Fostering in southern African Soricidae. Acta Theriologica 38: 451-452.

Blus L. J. and Johnson D. A. 1969. Adoption of a nestling house mouse by a female short-tailed shrew. The American Midland Naturalist 81: 583-584.

Buttler G. 1953. Ein Beitrag zur Sexualbiologie der Insectivoren unter besonderer Berücksichtigung der accessorischen Drüsen der Soriciden Crocidura leucodon Herm. und Crocidura russula Herm. Dissertation, Technische Hochschule Carolo-Wilhelmina, Braunschweig: 1-94.

Churchfield S. 1990. The natural history of shrews. Christopher Helm, London: 1-178+14.

Crowcroft P. 1957. The life of the shrew. Max Reinhardt, London: 1-166.

Dehnel A. 1952. The biology of breeding of the common shrew S. araneus L. in laboratory conditions. Annales Universitatis Mariae Curie-Skłodowska, Sectio C, 6: 359-376.

Dryden G. L. 1980. Observations of Mus musculus raised by Suncus murinus. Zeitschrift für Säugetierkunde 45: 249-250.

Grünwald A. and Möhres F. P. 1974. Beobachtungen zur Jugendentwicklung und Karawanenbildung bei Weisszahnspitzmäusen (Soricidae-Crocidurinae). Zeitschrift für Säugetierkunde 39: 321-337.

Haberl W. 1993. Zur Ökologie einheimischer Spitzmäuse (Soricidae, Insectivora) und ihres Lebensraumes am Beispiel eines Waldviertler Feuchtbiotops und experimentelle Bearbeitung ausgewählter ethologischer Fragestellungen. Dissertation, University of Vienna, Vienna: 1-265+211.

Haberl W. 1995. The Shrew Bibliography. A collection of more than 6000 references to research on the biology of the soricidae (Insectivora, Mammalia) and small mammal ecology. I. CD-ROM version. II. Printed version. Eigenverlag, Vienna: 1-299+3.

McGuire B. and Novak M. 1987. The effects of cross-fostering on the development of social preferences in meadow voles (Microtus pennsylvanicus). Behavioural and Neural Biology 47: 167-172.

McGuire B. 1988. Effects of cross-fostering on parental behavior of meadow voles (Microtus pennsylvanicus). Journal of Mammalogy 69: 332-341.

Michalak I. 1982. Reproduction and behaviour of the Mediterranean water shrew under laboratory conditions. Säugetierkundliche Mitteilungen 30: 307-310.

Michalak I. 1983. Reproduction, maternal and social behaviour of the European water shrew under laboratory conditions. Acta Theriologica 28: 3-24.

Michalak I. 1987. Keeping and breeding the Eurasian water shrew Neomys fodiens under laboratory conditions. International Zoo Yearbook 26: 223-228.

Niethammer G. 1950. Zur Jungenpflege und Orientierung der Hausspitzmaus (Crocidura russula Herm.). Bonner Zoologische Beiträge 1: 117-125. 
Riedman M. L. 1982. The evolution of alloparental care and adoption in mammals and birds. Quarterly Revue of Biology 57: 405-435.

Rozmus T. 1961. Les observations sur la conquête de la proie par le Sorex araneus Linnaeus, 1758.

Acta Theriologica 4: 274-276.

Slipp J. W. 1942. Nest and young of the olympic dusky shrew. Journal of Mammalogy 23: 211-212.

Vogel P. 1969. Beobachtungen zum intraspezifischen Verhalten der Hausspitzmaus (Crocidura russula Hermann, 1780). Revue Suisse de Zoologie 76: 1079-1086.

Wahlström A. 1928. Beiträge zur Biologie von Sorex vulgaris L. Zeitschrift für Säugetierkunde 3: 284-295.

Wahlström A. 1929. Beiträge zur Biologie von Crocidura leucodon (Herm.). Zeitschrift für Säugetierkunde 4: 157-185.

Received 12 February 1996, accepted 11 September 1996.

Acta Theriologica 41 (4): 438, 1996.

\section{BOOK RECEIVED}

THE SHREW BIBLIOGRAPHY. A collection of more than 6000 references to research on the biology of the Soricidae (Insectivora, Mammalia) and small mammal ecology. II. Printed version 1995. W. Haberl. Pbk, iii+ 299 pp. ISBN 3-9500483-1-6. Published and distributed by Dr Werner Haberl, Hamburgerstr. 11/17, A-1050 Vienna, Austria].

[The CD-ROM version is also available. More information on "The Shrew Bibliography" are on the author's internet homepage URL: http://members.vienna.at/shrew named "The Shrew(ist's) Site".]

This is a collection of 6109 references to research work on Soricidae. Papers and books on various topics (ecology, behaviour, anatomy, physiology, reproduction, development, genetics, systematics, taxonomy, palaeontology, evolution, trapping and research methods, laboratory breeding, zoogeography, conservation and many others) as well as unpublished data (eg contributions to meetings, dissertations, theses) have been considered. The important advantage of this book is including of the hard-to-locate references to old papers and those in journals not listed in databases. All references were multiply checked and compared with existing bibliographies to minimize errors. The bibliography should be a valuable and powerful tool for students of shrews and other small mammals.

L.R. 